\title{
A-IV-37 重症僧帽弁狭窄症，とくに三尖弁閉鎖不全合併症 の手術適応と成績
}

\section{国立大阪病院 心臓血管外科 \\ 田村栄稔山口明満大潼正己沢谷修 美濃地忠彦跡部正明北狩信夫}

三尖弁閉鎖不全（以下 TR）を合併した重症僧帽升狭 窄症（以下 MS）は一般手術成績も悪く, 積極的汕両 升の修復が行われている。われわ和は左室の駆出率（以 下 $\mathrm{EF}$ ) が $50 \%$ 未満の MS 症例を重症例と定義した。 1980 年当初上り $\mathrm{EF}$ が $50 \%$ 以下の 31 症例を TR 合 併群 (A 群), 非合併群 (B 群) とし比較検討を行ない 若干の所見を得たので報告する.

\section{対 象}

A 群は 19 例 (平均年令 53 才), B 群は 12 例 (平 均年令 52 才) であった。 術式は, A 群で MVR+TTAC* が 16 例, MVR + TVR が 2 例, $\mathrm{OMC}+\mathrm{T}-\mathrm{T}$ AC* が1例である.〔*T-TAC : tricuspid-tailouringannular constriction, 三尖升輪全周縫縮術了B 群では MV$\mathrm{R} 10$ 例， OMC が 2 例であった（表 1 ).

\section{結果}

A， B 両群で術前後の心カテーテルによる評価を和こ なった（図 1)。肺動脈楔入圧 (PAWP) は 21.6 $\mathrm{mmHg}$ から $12.4 \pm 2.4 \mathrm{mmHg}$ 一と有意の低下を示し (A 群)，B 群では $19 \pm 5.2 \mathrm{mmHg}$ から $15 \pm 63 \mathrm{mmHg}$ へと減少した。肺動脈圧はA 群 $53 \pm 27 \mathrm{mmHg}(27 \mathrm{~mm}$ $\mathrm{Hg}-115 \mathrm{mmHg})$ から術後 $33 \pm 5 \mathrm{mmHg}(26 \mathrm{mmHg}$ $44 \mathrm{mmHg}$ ) へと有意の低下を示した. B 群では術前 45 $\pm 23 \mathrm{mmHg}(29 \mathrm{mmHg}-106 \mathrm{mmHg})$ から術後 $42 \pm 12$ $\mathrm{mmHg}(29 \mathrm{mmHg}-63 \mathrm{mmHg})$ 一と幾分の低下を示し た. Cardiac Index (以下 C I) は, 術前 $2.19 \pm 0.32 l$ $\min$ から $2.78 \pm 0.29 \mathrm{l} / \mathrm{min}$ へと上昇 (A 群), B 群で も $2.05 \mathrm{l} / \mathrm{min}$ から $2.6 l / \mathrm{min}$ 一増加した. $\mathrm{EF}$ 法 で 48\% から 53\% へ，B群では 43\% から $60 \%$ へ之 とくに B 群で著明の増加をみた。 T-TAC の評価を拉こ なった (図 2), 平均右房圧 (RAP) は $8.9 \mathrm{mmHg}$ から 術後 $7.1 \mathrm{mmHg}$ へと， RVEDP は $9.1 \mathrm{mmHg}$ より $6.0 \mathrm{mmHg}$ へ之右心系に対する preload の減少がみら れた，肺血管抵抗值は，A 群で平均 $25 \mathrm{RU}$,であったが
術後 $12 \mathrm{RU}$ へと約 1/2 にまで低下，B 群でも $22 \mathrm{RU}$ から $16 \mathrm{RU}$ へと減少がみられた。

表 1 重症僧帽弁狭窄症 $(\mathrm{EF}<50 \%)$ : 31例

内訳

A) MS+TR : 19例

術式 MVR+T-TAC* : 16例

MVR+TVR : 2例

OMC+T-TAC* $: 1$ 例

(*T-TAC : Tricuspid Tailouring Annular Constriction)

B) MS : 12例

術式 MVR : 10例

OMC : 2例
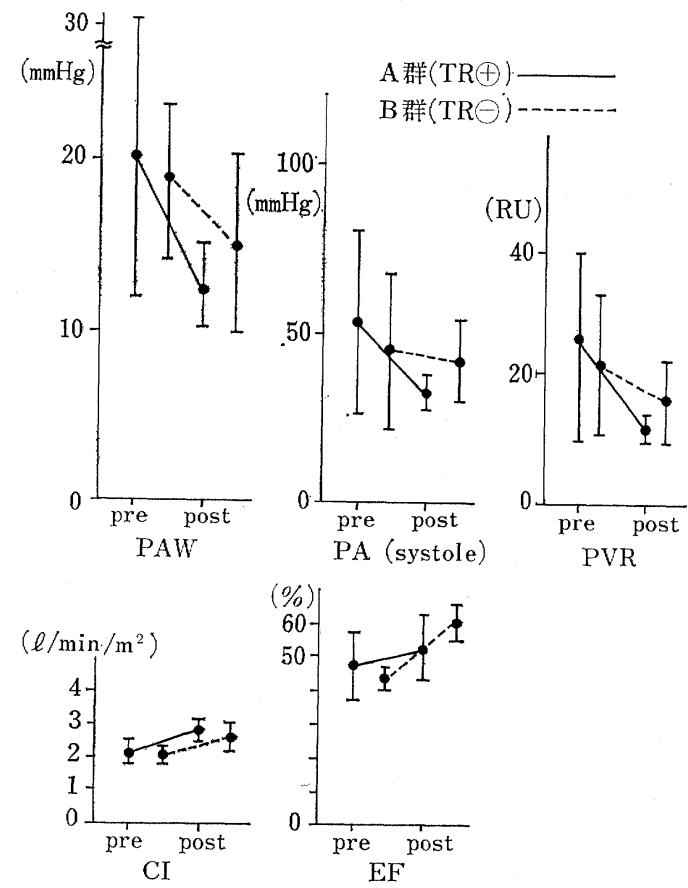

図 1 A 群，B群での術前後の心カテーテルによる比較 


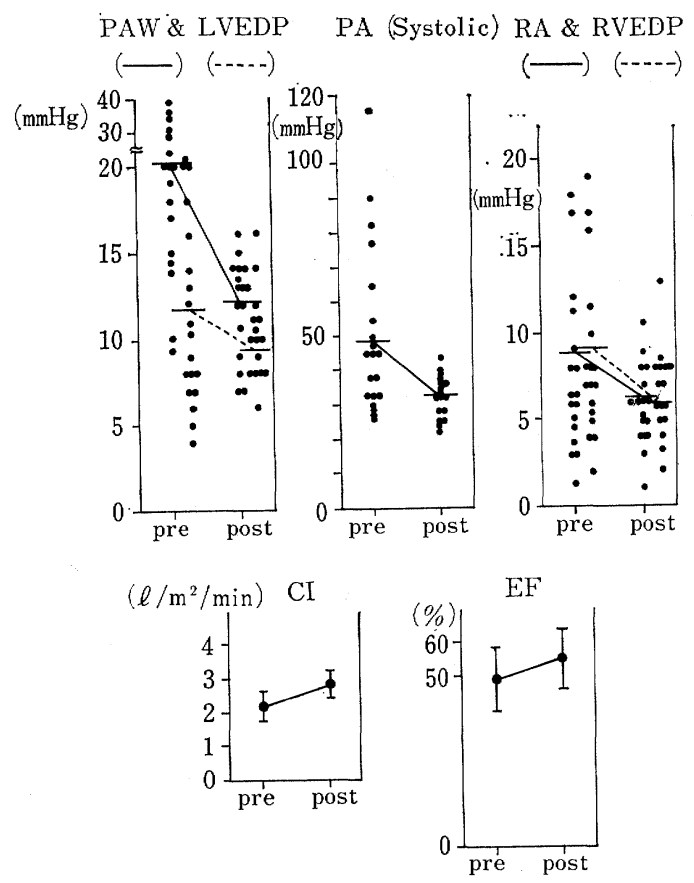

図 $2 \mathrm{TAC}$ 症例の術前後の血行動態の評価

\section{臨床症状の改善店並びに成績}

$\mathrm{A}$ 群の平均病悩期間は 15 年, B 群では 6 年と A 群 にくらべ短かった．CTRはA 群で75. $6 \%$ から術後 60.6 $\%$ へ，B群では $62 \%$ から術後 $57 \%$ へと縮少を示し た. NYHA による機能分数でも A 群，B群とも術前は III-IV度の症例が多く，A 群では $58 \%$ が I 度に，42\% がエ度にとどまった。 B 群では $67 \%$ が I 度に復帰し，

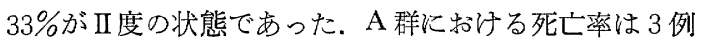
(15.8\%) 認められいずれも病院死である.内 2 例は いわゆる cardiac cachexia を呈し，術後 2 日目 LOS て，他の 1 名は遷延する呼吸不全のため 35 日目に死亡 した。 また術後 2 週目に rhythm failure による死亡が 1 例であった. B 群では死亡例はなかった。

\section{考察}

MS+TR における TR は一般に MS から進展した
機能的病変すなわち, 三尖弁輪の拡大が主原因といわれ る.われわれはこの考学から TRに対し三尖弁輪全周縫 縮術を過去 4 年間にわたり施行し, 術後心機能, 臨床症 状の改善をみた。 MS+TR は MR+TR と比較し, 積 極的な TRの修復が必要といわれる，その理由の一つに はMS による術前からの肺循環障害の程度が大きいこ上の と, また術後増加した左室の前負荷に対し心筋は術前以 overload を強いられるため，放置された TR は術後の LOS の大きな要因となると考兄られる，TRの評価は 術前の右室造影，ドップラーエコーが参考となるが，強 心利尿剤や安静により TR は臨床上かなりよく control される症例もあり見かけ上 TRが軽度でも, その存 在が疑われたなら術中三尖弁の検索が最も大切であるら. 術後肺動脈楔入圧の低下以大きく, 左心系に対する完全 な修復が必要とされる根拠の一つといえる，肺高血圧は， TR 群で全体の $47 \%$ ，非 TR 群で $42 \%$ と前者にやや 多くみられ，肺動脈王も術前高值を示す例が多かったが， 術後はTR群で有意に低下しており, 肺高血圧の存在は 手術に対して大きな Risk とはなり難いと考えられた。

$\mathrm{EF}$ の改善度沙非 TR 合併群で大さかったがこれは術 後心カテーテルの時点では未だ充分に右室負荷がとれて いなかったためと考光れた。 以上より，MS + TR， MS の比較に拈いて，心カテーテル上はとくに有意な差 が見出せず，むしろ急性期を乗り切った MS+TR 群で は術後の回復も MS 単独群にくらべ劣ることはないと結 論された.

\section{結語}

$\mathrm{EF}<50 \%$ の重症 MS 31 例を，A） TR 合併群，B) TR 非合併群に分计比較検討した。

1）肺動脈楔入王，肺血管抵抗は A 群で大きく術後 の急激な改善がみられる。

2) 心係数の改善度に差は認められない.

3）左室駆出率の改善度はB 群で大きかった.

4）死亡例は A 群で大さかったが，これは，術前より の肝，腎，肺機能の低下 (cachexia) が大きな誘と 考完られた. 